\title{
Rule of law, corruption and democratic accountability in the course of EU Enlargement
}

Arolda Elbasani, corresponding author, Email: arolda.elbasani@eui.eu

Senada Šelo Šabić

\begin{abstract}
Why has the EU's promotion of Rule of Law (RoL) triggered different and largely surface-thin reforms across countries subject to a similar frame of enlargement in the Western Balkans (WB)? We hypothesize that the domestic (non)enforcement of EU promoted rules depends on the mobilization of politically autonomous constituencies of change - organized advocacy groups and autonomous state institutions - which amount domestic accountability. The empirical investigation focuses on the prosecution of political corruption as empirical foci to assessing the travails of EU-promoted rules in the domestic context. Specifically, we trace the role of (1) EU's RoL promotion strategy, (2) political resistance and (3) domestic accountability in explaining different records of prosecution of political corruption in Albania and Croatia.
\end{abstract}

KEYWORDS: EU Enlargement; Rule of Law; Corruption; Democratic Accountability; Croatia; Albania. 


\section{Introduction}

Evidence on the transposition of EU rules at the receiving end of enlargement shows quick and maybe coinciding, but at the same time easily reversible, and largely surface-thin, patterns of compliance (Dimitrova 2010; Elbasani 2013). The underlying gap between massive formal transfers and shallow or reversible enforcement of the EU rules is particularly evident in the area of RoL across the WB countries, where this issue surfaced as 'a major problem' (Mendelski 2015; European Commission 2006). Neither the EU's revamping of its RoL promotion strategy nor the demonstration of formal compliance among target countries sufficed to turn around the poor record of reform. International indices show meagre 'net' gains from enlargement policy in the period 2005-2015: judicial independence remained the same or regressed in 6 out of 7 WB countries; the regional average of corruption lingered at a low 4.79, with 7 being the worst score (Freedom House 2015). Even Croatia, which became subject to accession negotiations in the period 2004-2011, recorded deteriorating indices of judiciary independence (4.25 in 2011 and 4.50 in 2015 as compared to 3.75 in 2001). BTI scores of RoL confirm a decline of 0.5 points during the period when Croatia was at the very peak of negotiations, 2006-2012 (BTI 2016a). Overall, indicators on the progress of RoL don't corroborate any reform 'breaks', which we would expect from the transformative power of enlargement, including during accession negotiations when EU rewards are the most tangible.

This article conceptualizes and investigates the factors that explain the travails of (non)enforcement of EU-promoted RoL transfers at the receiving end of enlargement. Taking stock of the identified gap between formal compliance and rule enforcement, we highlight the 
problem of political resistance and incorporate the role of accountability in order to explain the domestic evolution of RoL transfers. Specifically, we suggest that rule enforcement depends on the mobilization of vertical and horizontal accountability mechanisms, each capitalizing on a set of politically autonomous agents of change. It is these mechanisms that enable scrutiny of political resistance, especially in captured polities where arbitrary elites frequently revamp formal EU transfers.

We assess the domestic 'life' of EU-promoted RoL criteria focusing on the prosecution of highlevel political corruption. Prosecution of abuse of power serves as suitable empirical foci to evaluate the role of EU policy and domestic factors for several reasons. First, it is sufficiently specific to empirically assess the 'net effects' of the EU transfers. Second, it synthesizes progress in key dimensions of EU's RoL criterion - judiciary, corruption, organized crime, and equal application of law. Third, it is an area that sparks resistance from ruling elites keen to preserve the spoils of power. Finally, the issue also prompts the activity of alternative local constituencies to hold their office-holders to task for their abuses.

The empirical analysis draws on a cross-comparison and in-depth case studies of Albania and Croatia. Both cases display crucial similarities in terms of potential explanations - they are targeted by a similar policy of enlargement, premised on similar institutional stages, package of incentives as well as attention to RoL; They further display growing political consensus on and formal compliance to advance towards the goal of EU membership; Additionally, they both feature a deep-rooted system of political patronage that prompts respective elites' resistance to prosecution of corruption. Yet, both countries advanced at a different pace in the ladder of 
accession, while recording different mobilization of local constituencies able to amount accountability. The combined comparative and in-depth insights from the cases enable us to trace the role of similarities and differences in explaining the successful prosecution of VIP cases in Croatia and the impunity of political class in Albania.

The argument proceeds in three sections. Section one analyses existing expectations on the transformative power of the EU and introduces domestic accountability as a crucial factor in explaining (non)enforcement of EU transfers. Section two maps out the evolution of the RoL criterion of enlargement as applied in the WB. Section three investigations how (1) EU enlargement policy, (2) political resistance, and (3) domestic accountability play out to explain the record of prosecution of political corruption in Albania and Croatia.

\section{Enlargement transfers, reformist elites, and patchy reforms}

Empirical studies on the Europeanization of RoL during the process of enlargement tend to highlight frequent legal/institutional compliance that had neither fundamental nor lasting effects in most post-communist candidates (Mendelski 2015; Boerzel and Risse 2013). Such reforms

proved susceptible to reversals, especially once the immediate pressure and monitoring emanating from the EU ceased to exist, demonstrating weak ownership of the rules transplanted as part of enlargement deal (Ganev 2007). As suggested in retrospect, massive transfers of legal norms to Eastern Europe might have actually undermined a crucial function of RoL - the legal certainty that frames actors' mutual expectations along routinized procedures (Nicolaidis and 
Kleinfeld 2012: 19). This façade form of Europeanization was particularly eminent among WB countries facing difficult 'initial' conditions. The region's specific trajectory of transition, marked by contestation of territories, state dissolution, and the emergence of new entities, created a vacuum of institutional restraints. The weak institutional infrastructure, in return, allowed political elites ample discretion in crafting new rules subservient to interests of the day while shaping a patchy mode of institution-building (Kleibrik 2015). Most problematically, it ushered in 'unholy' alliances between governing actors and mushrooming illegal networks, which managed to capture decision-making mechanisms (Kostovicova and Bojicic-Dzelilovic 2008: 19). In the context of state capture by particularistic interests - political or criminal formal institutions often degraded into empty shells, or even worse 'political weapons' serving their crafters. As Carothers notes (2006: 4), the primary obstacles to reform in such captured polities 'are not technical or financial, but political and human. Rule of Law reform will succeed only if it gets at the fundamental problem of leaders who refuse to be ruled by law'.

Still, mainstream assumptions that animate Europeanization via enlargement research typically assume a top-down model of rule transfers predicated on the pressure of EU conditionality, the appeal of EU rewards, and the power asymmetry that the EU holds in the process (Elbasani 2009). Accordingly, the enlargement strategy whereas the EU sets the criteria for joining the club, monitors compliance, and dangles substantial rewards in response, tips the balance of power in favour of domestic reformists (Schimmelfennig and Sedelmeier 2006: 99). Those reformist 'constellations' of power - political parties and governing actors - who benefit from the EU re-distribution of power, are singled out as the most proximate source of reform (Schimmelfennig 2007). EU enlargement strategy is expected to work via similar conduits of 
change also in the WB: "The enlargement process continues to have a "democratizing effect" as WB candidates and proto-candidates respond to the incentives of EU membership: political parties have changed their agendas to make them EU-compatible and governments have implemented policy changes to move forward in the pre-accession process' (Vachudova 2014: 122). Indeed, target constellations across the WB have gone a long way to embrace the goal of EU integration, fine-tune their programmes, and undertake large-scale institutional imports during the course of enlargement. The nexus EU incentives-reformist elites-domestic compliance, however, fails to recognize that it is exactly those domestic 'conduits' that do informally resist the enforcement of adopted rules - effectively investing in the status quo (Joireman 2015; Mendelski 2015). The incentive-based model of compliance, thus, fails to reckon with the complex strategies of political resistance, and the political and human factors that undermine the promotion of RoL. By taking informal resistance out of equation, the EU incentives end up empowering political elites who play a double game: formal compliance with the EU rules on the one hand, and informal stratagems that undermine promoted rules, on the other.

\section{Domestic ownership and accountability mechanisms}

If elites' compliance with the EU rules is a surface-thin indicator of reform to the extent that they frequently take back during implementation stages what they committed to at the decisionmaking level, the domestic life of EU-promoted reforms depends on the mobilization of local constituencies with the capacity to scrutinize elite behaviour and inspect the enforcement of rule transfers. Bringing into the analysis alternative local constituencies of change requires an 
expansion of the array of domestic actors that serve as conduits of the EU agenda, on the one hand (Nicolaidis and Kleinfeld 2012), and the reconceptualization of the role of accountability during the process of rule enforcement, on the other (Merkel 2014).

Comparative research on the consolidation of democratic regimes suggests two crucial accountability mechanisms - vertical and horizontal - each capitalizing on different actors who serve to monitor elected power-holders while entrenching adopted rules in a net of social and institutional safeguards (Schedler et al. 1999). Vertical mechanisms point to the input of organized social groups, particularly the media and non-governmental organizations (NGOs), in disclosing political abuses and raising social demands for RoL. The enlargement studies are not oblivious to the role of civil society, which is often a beneficiary of the EU's political empowerment and distribution of funds. As Joireman (2016: 317) notes, 'EU conditionalities...create a political space for interest group engagement and the development of a "watchful constituency", which may eventually lead to the enforcement of laws...'. Advocacy groups are found to create transparency about arbitrary government 'deals' and to pressure the political elite to adhere to the EU standards in various cases and areas of reform (Grigorescu 2006; Wunsch 2016). To serve their role as 'watchful constituencies', however, advocacy groups need to be independent of politics and/or clientelistic interests (Mungiu-Pippidiu 2010). Yet, elite-centered analysis of EU enlargement tends to incorporate civil society as, at best, an auxiliary actor whose input is neither conceptualized nor scrutinized. The EU world of projects, for its part, tends to promote major 'professional' organizations able to compete for funds, despite the political connections and interests that they may nourish. Academic studies, similarly, 
treat NGOs as an automatically independent constituency, thus failing to question the political services that might loom underground.

Horizontal mechanisms, by contrast, draw attention to the role of checks and balances within the constitutional architecture of the state. The autonomous institutions - the presidency, judiciary, and other politically independent units - serve to check and prevent the abuse of power by powerful executives (Merkel 2014). Here too, the EU enlargement tools - particularly political empowerment and funds - can empower otherwise fragile independent institutions to exercise their supervisory functions. Certainly, in the course of enlargement, the EU has invested ample financial sources - budgetary assistance, training and assistance for the improvement of infrastructure, management and administration - to embolden autonomous institutions. EU focus on technical capacities, however, has often dismissed the impartiality dimension such as independence, corruption and effective separation of targeted institutions (Mendelski 2013: 103). The failure of EU funding to differentiate between the formal status of such institutions as a mechanism of checks and balances, and their de facto working as politically-controlled entities, whose strings are pulled by the very elites they are supposed to check, may have the opposite effects of empowering mechanisms that serve political resistance. Compliance-focused mainstream Europeanization studies, too, randomly fail to untangle between the formal elite commitments and the informal strategies that keep domestic institutions hostage to patronage schemes.

Based on these insights, we argue that the enforcement of EU-promoted RoL criteria depends on the mobilization of politically independent constituencies of change - (1) advocacy groups and 
(2) autonomous state entities - which can keep power holders accountable and entrench EU rules into a net of social and institutional safeguards.

\section{The 'living' criterion of RoL}

During the EU enlargement in the WB, the RoL criterion emerged as one of the top priorities and a major concern of the evolving EU policies. Given the poor state of RoL across the region, the EU enriched the standard Copenhagen criteria with a 'second generation' RoL promotion strategy, which highlights the implementation and irreversibility of reforms. The gradually evolving second generation strategy foresees: clear referents, time-sensitive targets, thresholds of monitoring, linkages between evaluation and progress of accession, and an elaborate definition of progress in the area of RoL. The 2006 Consensus on Enlargement heralded revisions of RoL promotion strategy by introducing 'enhanced rules governing the accession process' and the use of benchmarks 'for opening and closing...individual chapters' (European Commission 2006b). 'Judicial reform, administrative capacity, the fight against corruption and organized crime' were singled out as issues that needed to be addressed early on in the accession process. The foreseen steps would allow for a timely and detailed assessment of RoL while making sure that the findings '[fed] into the pace of accession' (Ibid.). Progress, moreover, was redefined as nothing less than 'a satisfactory track record of implementation', thus drawing attention to the need for cumulative and sustainable results (Ibid.). 
The Consensus was to send a general message that no country could progress on the ladder of accession without clearing RoL problems first. Yet, its concrete innovations targeted first and foremost the management of accession negotiations with Croatia, the only WB country progressing sufficiently to open negotiations in 2006. The 2004 negotiation framework with Croatia had already foreseen new tools- a new chapter dedicated to RoL (Chapter 23) and a benchmarking scheme for opening and closing each chapter - in order to monitor more closely the progress of RoL. The first subsequent assessment of Croatia's progress pinpointed at corruption as 'a serious problem' and at the judiciary as an area demanding 'serious attention' (European Commission 2005: 33). Near the end of negotiations, the EU reports became particularly vocal on the issue of political resistance to RoL: "political bodies support the centrally coordinated anti-corruption efforts only in words' (European Commission 2009). The 2010 opening benchmarks for Chapter 23 asked the Croatian authorities to prepare action plans that tackled the issue specifically; the closing benchmarks required also demonstration of a track record implementation of those plans (Nechev 2013). Closing benchmark no 5 required, 'the demonstration of....unbiased investigations, prosecution and court ruling in ...corruption cases at all levels.' Even after the conclusion of negotiations in 2011, a specific monitoring mechanism was set up to assess the pace of reforms until Croatia's eventual EU membership in 2013.

The emphasis on RoL quickly spilled over into the EU relations with other Balkan countries positioned at different stages of accession. In the case of Albania, both the 2006 and 2008 European Partnerships ranked the 'judicial system' and 'fight against corruption' among the urgent issues the country needed to deal with. The 2010 opinion on country's readiness to take on the obligations of membership provided specific detail on the state of RoL. On the judiciary, the EU 
noted: 'risks to independence of judges as well as...a lack of efficiency in general' (European Commission 2010: 20). On corruption, the Commission found that it 'remains a particularly serious problem' and noted 'a lack of track record of convictions in corruption cases' (Ibid., 97). Any decision to open accession negotiations was bound to country's progress in areas of RoL independent judiciary, fight against corruption, and fight against organized crime - indeed the pillars of the reinforced RoL criterion of enlargement.

The RoL criterion received yet another boost when the EU was foreseeing opening of accession negotiations with a host of other Balkan countries. The 2011 Enlargement Strategy pointed at RoL as 'a continuing major challenge and a crucial condition for countries moving towards EU membership' (European Commission 2011: 4). The next Enlargement Strategy flagged substantial expectations on the revised RoL promotion policy: 'reforms need to be deeply entrenched with the aim of irreversibility' (European Commission 2012: 3). Montenegro, the first in line to open accession negotiations, became also the main trial case of evolving EU policies (Nechev 2013: 2732). Albania would also receive candidate status only after a special 2014 report on RoL suggested decisive action in the prevention and fight against corruption. Afterwards, RoL came to occupy a prominent section of progress reports. Meanwhile, the EU officials would use every chance to remind Albanian authorities on the necessity of judiciary reforms and adequate investigation of corruption, seemingly the only condition for opening accession negotiations.

\section{Explaining track records of prosecution of political corruption}




\section{Party patronage and the entrenched system of rents and spoils}

During their first decade of transition, Albania and Croatia saw the progressive build-up of oneman authoritarianisms that made use of an extensive system of political patronage to get hold of the state. In Croatia, Tudjman, a former Yugoslav general, who founded the nationalist Croatian Democratic Union (HDZ) and presided as 'the father of the nation', accumulated extensive powers for himself during the period 1990-1999 (Boduszyński 2010). In Albania too, Berisha, a long-term career communist who took the reins of the first anti-communist opposition, the Democratic Party (DP), and later the country's presidency, concentrated most decision-making powers around his presidential office in the period 1992-1997 (Abrahams 2015). Both leaders 'played' democracy and flirted with the idea of European integration, but only to the extent that the democratic institutions didn't threaten their grip on power, and Westerners tolerated them as a 'stabilizing force' in the region. Behind the façade of pro-democratic and pro-European rhetoric, both countries' strongmen cultivated a system of political patronage in order to control formal decision-making processes (Abrahams 2015; Boduszyński 2010). The recruitment of political militants and personal loyalists in key state institutions - privatization boards, public companies, judiciary, security services, public apparatus and even the academic system - was instrumental in creating state structures, which served their political masters and fortified hegemonic party rule. Opportunities of privatization and black markets provided ample spoils to feed in the system of political patronage and corruption, all tied to the highest echelons of power (Boduszyński 2010). The possibility to craft new institutions in key moments of transition, moreover, allowed party oligarchs to rule without effective constraints. The use of nationalism in Croatia and anti-communism in Albania provided also the ideological zeal to neutralize critics, 
who were forcefully shut down as 'enemies of the nation' in the former (Grubiša 2010: 77) and 'dangerous communists' in the latter (Elbasani and Lipinski 2011). Consequently, the state slipped into a hierarchical system of rent and spoils to be distributed among party cronies via privatization schemes, state employment, public contracts and subsidies.

Despite the build-up of similar authoritarianisms that preyed on political patronage, one decade into the transition Albania and Croatia parted ways in their path to regime change. By 1997, mismanagement of the economic and political transition in Albania drew the masses to the streets, this time to protest the anti-communists' governing project. The subsequent collapse of the state, and ensuing chaos, enabled the flourishing of organized crime. The winner of the 1997 elections, the Socialist Party (SP), had a weak hold on power to lead much needed institutional changes. Instead, it was the multilateral organizations and bilateral donors that provided the military, diplomatic and financial support to patch the system together (Elbasani 2009). Major traits of the initial transition - political patronage, state capture and abuse of public office for private and political interests, however, survived the reshuffled institutional order. As Abrahams (2015: 471) suggests, the Socialists 'fine-tuned corruption, weaving it through business, tenders, third parties and trade. In every important decision of government, a private interest lay behind'.

In Croatia, the death of Tudjman in 1999 released some of the accumulated political conflicts within his party and the larger political scene. The 2000 rotation of power ushered in a liberal coalition of parties whose program read like a European 'wish list' - institutional change and the restoration of RoL along European integration. International structures lent support to the new coalition with concrete incentives for accession to NATO and the EU, including the swift 
conclusion of the Stabilization and Association Agreement in 2001. Large-scale reforms, including the restructuring of the judiciary and formal initiatives to curtail corruption, brought the country closer to the EU. Still, abuse of the public office and illicit forms of enrichment remained key features of Croatian political order long afterwards (Grubiša 2010).

\section{Commitment to EU integration and persisting corruption}

By the mid-2000s, both countries had moved to forge large social and political consensus on the goal of EU integration. Reformists, betting their fortunes on the progress of EU membership, gained strength in politics and society (Elbasani 2013). The anti-Western rhetoric and muscleflexing militants of the initial transition were literally swapped with soft-speaking professionals fluent with the language of the West and reform. These pro-European pundits reworked parties'

programs, advocated policy changes and framed government strategies within the priorities of EU integration. Even the parties that fashioned the patronage system during the early transition embraced a pro-European image once they returned to power, HDZ in 2003 and DP in 2005. In Croatia, Sanader, a close Tudjman associate and the new leader of HDZ, ran for office with an EU-centered platform. He became the Prime Minister (PM) that led his country into adopting the expanding acquis communitaire plus the enhanced Copenhagen criteria in the period 2003-2009. In Albania, Berisha, the historical leader of DP, similarly embraced EU integration as the grand objective of his governing project in the period 2005-2013. He became the PM to supervise country's NATO membership in 2008 and push the application for EU membership in 2012. Both DP- and HDZ-led executives further pledged 'clean hands policies', which had begun to cement as a 'major obstacle to further integration' for all countries in the WB. The reforms 
required to enter the EU needed a 'prime minister' not a 'crime minister', suggested the incoming Albanian PM, with a reference to the corruption allegations against his predecessor (Abrahams 2015: 473). Political declarations, formal strategies, and institutional packages to tackle corruption emerged as the very hallmark of DP's and HDZ's reshuffled style of governance.

The embrace of EU integration, however, more often than not went hand in hand with the political exploitation of a deep-rooted system of rents and spoils. A 2005 report on Albania pointed the finger at politicians who 'directly or by collusion with criminals and/or business people steal from the public...or engage in a range of corrupt strategies (OECD 2005: 24). Experts in Croatia similarly voiced 'strong disbelief in the...readiness to fight corruption among members of the ruling political elite' (Štulhofer et al. 2008: 6). Croatian experts also doubted their politicians' promises as 'window dressing intended for the EU decision-makers' (Ibid.: 16). In 2013, the coordinator of Transparency International Tirana (TIA) explicated the chain corruption-organized crime-legal impunity in scary terms: 'corruption is registering a new physiognomy in a favorable political environment, with characteristics like a new system for money laundering,...the capture of the state through the control of procurement and privatization, human and narcotics trafficking and the impunity of high state officials before the justice system' (quoted in Likmeta 2013).

Despite political elites' similar resort to preying on public resources, by the mid-2000s investigations into political misconduct reached the highest echelons of power in Croatia, while recording total impunity of office-holders in Albania. In Croatia, the investigations of second-tier 
officials that started in 2006 gradually gained steam to target also the 'big fishes'. Sanader's 2009 resignation from all his public posts, arguably under the pressure of corruption allegations, paved the way to a chain of famous arrests - a deputy prime minister, two ministers, the treasurer of HDZ, several directors of state-owned companies, and Sanader himself. In 2012, Sanader was sentenced to ten years and the return of half a million euros for illegal kickbacks totaling around ten million euros (HYPO bank). In 2014, he was sentenced to another nine years and the return of two million euros in another case involving the embezzlement of public funds (FIMI media). In the same proceeding, HDZ was also found guilty and stripped of four million euros worth of illegally acquired assets. Two other trials - Planinska and TLM-HEP - that were still ongoing in 2016, implicated Sanader for the embezzlement of around ninety million euros worth of assets. In 2015, the Constitutional Court demanded a new trial in the HYPO Bank case and the Supreme Court decided the same in the FIMI case. Both decisions raised suspicions of a rollback in the functioning of the justice system. Yet, prosecution of political corruption remained a steady feature of Croatian politics as high profile cases - a former Minister of Economy, a former Minister of Transport, a former Head of the Chamber of Commerce, the influential Major of Zagreb, the Executive Director of a powerful football club, and various public-company managers - were continuously subjected to complex investigative schemes.

At around the same period, Albania positioned itself firmly at the opposite end of enforcement of EU-promoted RoL, as assessed through the track record of the prosecution of political corruption. The investigation of all political cases were persistently hindered, withdrawn, or dragged to a dead end during different stages of 'due' process (BTI 2016b). A 2007 case involving the then Minister of Interior for abuses that allegedly cost the state around 230 million 
euros was closed down on account of 'procedural' delays (Primatarova and Deimel 2012). Other cases against the same politician, who continued to occupy major political posts and ultimately the top DP leadership, were also postponed, hindered and blocked during the judicial process (BTI 2014). Another 2008 case involving several then ministers, and the son of the then PM, in the explosion of a military facility that killed 26 people - the so-called Gerdec case -similarly ended without proper investigations or indictments even if some of the alleged abuses appeared in the New York Times (Primatarova and Deimel 2012). A 2011 case involving illicit deals between the then Minister of Foreign Affairs and then Minister of Economy, broadcasted on TV, also ended with the clearing of the protagonists from any charges, although US experts certified the broadcasted video as authentic (BTI 2014). An independent report on high-profile cases of corruption suggested 'extensive use of non-democratic proceduralism...for political and individual purposes' (Primatarova and Deimel 2012: 7).

\section{The ubiquitous role of civil society}

In both our cases, vertical accountability mechanisms as activated by the media and NGOs, helped to draw attention into the saga of political corruption and obstacles to investigations. Yet, these groups' engagement with political misdeeds, more often than not, reflected their own enmeshment with politics and/or clientelistic interests. Media reporting, especially of those outlets that fell into the larger economic portfolio of owners with interests in other businesses, were particularly tied to the prevailing system of political patronage. Political elites proved ready to please such media owners with lucrative state contracts, privatization deals, and expensive advertisement contracts in return for rectifying their line of reporting (Krešić 2012; BTI 2014). 
The result was the consolidation of dominant outlets that became the mouthpieces of specific sections of the political spectrum. On issues of corruption, these politically-controlled outlets helped to convolute and relativize responsibilities by favouring certain sections of the political spectrum and demonizing others.

Whereas the media provided ample, but confusing, and often times politically-motivated accusations and counter accusations, it was the mobilization of advocacy groups that enabled deeper scrutiny into the problem of corruption. In Croatia, most issues that entered the loophole of RoL conditionality and began to preoccupy the leading political class had already been in NGOs' agenda a decade earlier (Bosanac 2014). GONG (Citizens Monitor Elections in an Organized Manner), for example, took on the fight against corruption, at least since 1997. Conditionality only brought the issues that worried civil society from the margins of civic activism to the centre of the political decision-making process, while affirming the work of NGOs that were previously denigrated as traitors of the independent republic by the ruling elite. Throughout accession negotiations, Croatian NGOs collaborated with the European Commission as one of its most reliable allies, not only because of the opportunity to receive systematic financing, but also because of the political influence they gained due to the negotiation process (Ibid; Wunsch 2016). Quite often, moreover, the EU and NGOs found themselves on the same side in scrutinizing the work of the government. By conducting research, writing reports, and leading monitoring initiatives, the Croatian advocacy groups furnished much needed insights into the implementation of the anti-corruption legislation. Specifically, GONG, joined by a myriad of other organizations - Transparency International Croatia, Croatian Helsinki Committee, Civic Initiative, Centre for Peace Studies, Dokumenta, Youth Initiative for Human Rights, etc. - 
enabled the so-called shadow monitoring, which centred on various dimensions of RoL. Their findings informed EU-decision makers and were incorporated into the EU's annual assessment of Croatia's progress. Towards the end of the negotiations, around 60 organizations cooperated to build-up Platform 112 (named after the emergency number in the EU) and identify guidelines for entrenching RoL in the long run. After accession, this powerful local coalition for RoL took over to replace the vacant EU role by probing consecutive governments on the implementation of the identified guidelines. The Platform gained visibility in denouncing the reversals noted after Croatia's accession in 2013 and especially after a conservative HDZ-led coalition came to power in 2015. By then, the EU institutions and foreign embassies started re-consulting with advocacy groups on the sustainability of EU standards, thus replicating the practice of mutual cooperation that proved successful during accession.

In Albania, the form of civic advocacy, and often times the political connections nourished by major NGOs, were hardly conducive to the potential role of civil society as a watchdog of politics. The silence of the civic sector on issues of corruption goes back to the mummified style of the society inherited from the ancient regime, which had managed to crush all autonomous social groups (Chiodi 2008). After the fall of communism, the idea and practice of civil society entered the country through donors' aid policies, which shaped a specific mode of civic action concentrated in the capital, steered by career-oriented individuals with skills to penetrate the world of funds, shaped by donor-set priorities, and often too detached from the larger society and its concerns (Sampson 1996; BTI 2014). This kind of civil society also preyed on close connections with politics: prominent Albanian politicians registered their 'personal' NGOs, which then benefited from the connections and knowledge they attained while in power 
positions; advocacy leaders progressively enrolled in parties' lists of experts and electoral candidates, effectively grabbing major government posts; and public funds designated for the civic sector typically went to associations close to the majority of the day, often in return for progovernment activities (BTI 2016b). This complex enmeshment between NGOs and politics merged advocacy work, foreign funds and political agendas in a vicious circle of conflict of interest (Chiodi 2008). The Institute for Contemporary Studies, one of the best-funded organizations, for example, was pioneered and run by a prominent DP politician and his close associate militating in the same party when the first moved to occupy major ministerial posts; MJAFT (Enough!), the flagship of the successful advocacy network, was also ideated by a current SP politician who capitalized on high-level advocacy posts to jump start a stellar political career -head of a new party, SP-minister and then SP-supported Meyer of Tirana. The European Movement Albania, another thriving fund raiser, was similarly championed by an SP politician in between his political positions in the Ministry of Integration to (current) Minister of Foreign Affairs. Even TIA, the crucial organization reporting on corruption, was steered by a former journalist close to the DP, which strategically placed him in a grant distribution position- the board of the State Agency for Support of Civil Society. Donors' preferences for 'professional' organizations successful in fund raising, which tend to be also the best-linked ones, has propelled the political dimension of advocacy work, and marginalized the potential input of more peripheral civic activity in the battle for enforcement of RoL.

The (non)functioning autonomous institutions 
The civil society, with all its pitfalls, contributed to raise public concern and provide local expertize, but it was specialized institutions within the constitutional hierarchy of checks and balances that ultimately took their office holders to task for their abuses. Even in Croatia, reporting on corruption didn't deliver until the Bureau for the Suppression of Corruption and Organized Crime (USKOK) accumulated sufficient legal powers and expertise to investigate political cases. The creation of USKOK capitalized on a relatively well-functioning system of separation of powers, which Croatia enjoyed before and beyond accession negotiations (BTI 2016a). Both presidents that succeeded Tudjman - Stipe Mesić (2000-2010) and Ivo Josipović (2010-2015) - adopted a neutral profile regarding key state appointments and leadership of the presidential office. USKOK, first envisaged by the governing coalition back in 2001, accrued new competences during the accession negotiations. In 2005 and again in 2007, the Croatian Parliament, under pressure from the EU, voted to assign USKOK 'extraordinary powers' to inspect personal financial data, freeze assets, as well as conduct undercover operations, sting operations, and wiretaps. The appointment of Cvitan, a communist-era prosecutor, at the helm of the institution in 2005, provided also the necessary leadership to steer ongoing investigations (Kuris 2012). Cvitan succeeded to recruit a core of talented and trusted prosecutors; establish strict protocols to protect the leaking of information; manage the Bureau's good collaboration with other investigative units within the system; and seek training, assistance and information from key EU agencies in order to sort out complex cases (Ibid.). The public sympathy that the Bureau managed to amass helped it attain much-needed information and raised the political cost of possible intervention into its investigations. Indeed, by 2006 USKOK started tackling complex cases of corruption including privatization deals, corruption among university professors, bribes related to war-veteran status, and finally abuses of office among the highest echelons of political 
power. The vocal support of Sanader's successor, Jadranka Kosor, for prosecution of corruption provided also political impetus during a critical juncture of the process. In the multi-year investigation of the Sanader cases, prosecutors were able to go back to over two decades of what they called 'war profiteering' in order to document his illicit gains - a luxury villa, custom-made tuxedos, a $€ 150,000$ watch collection, and the historical art and suitcases of cash he stashed with his butcher before fleeing the country. By 2015, USKOK had managed to prosecute more than 2000 defendants with a conviction rate of over 95\%. The success of these investigations had clear political repercussions: 'It's much easier now to try a high-level politician... A message was sent' (quoted in Kuris 2015: 15). USKOK's front line contribution in the fight against corruption turned it into a weighty power that ensured the enforcement of RoL and helped the country clinch EU accession.

In Albania, by contrast, investigative institutions never gained sufficient autonomy to reach the power holders. Albanian presidents, who have the constitutional prerequisites to nominate key posts across the hierarchy of independent institutions, often assumed open political affiliations and helped infiltrate party cronies within the system of checks and balances, including the judiciary. The DP proved particularly successful at investing in presidents that pursued its political agenda. Bamir Topi was number two in the DP leadership before ascending to the post of the presidency in the period 2007-2012. His successor, Bujar Nishani, also came from the rounds of DP hierarchy and acting Ministers of the DP cabinet just before being voted into the position of Presidency in 2012. Although all the DP-nominated presidents served their party line, Nishani gained particular reputation for aligning the country's highest office almost exclusively to the positions of the party that voted him in that post (BTI 2016b). During his presidency, the 
separation of powers reached the lowest point of the last decade (Freedom House 2015). Key presidential appointments frequently went to DP-suitable candidates while relations with the ruling SP majority degenerated into frequent legal blockages and back and forth accusations. The political capture of the judiciary, however, is deeper rooted to the initial 'reforms' undertaken in the period 1992-1996, when most communist-era judges were replaced with 'anti-communist' loyalists. That contingent of judiciary appointees, who were hastily trained through a course lasting 3-6 months, was catapulted into decision-making positions of the judiciary hierarchy. Since that cohort of judges owned their careers solely to then ruling party, they became the Trojan horses of party patronage schemes within the system via controlling the promotion of personnel, allocating 'delicate' cases to suitable staff, and doctoring the final decisions when necessary to advance their careers. Dissenting candidates, even when party-affiliated, were systematically purged and politically denigrated. In 1994, Zef Brozi, then Head of the High Court (himself a former DP parliamentarian) was famously accompanied by a convoy of the US Embassy on his way to escaping the country, after a well-publicized conflict with the DP leadership. In 2007, it was the turn of the General Prosecutor, Sollaku (also a former aid of then PM Berisha) to be jettisoned out of office following acrimonious relations with the ruling majority. Sollaku's successor and the only woman to ever hold that position, Ina Rama, was similarly removed through contested procedures as soon as President Nishani took office in 2012 (BTI 2014). Before removal, Rama was personally denigrated as a 'boulevard prostitute' by the highest echelons of then executive, arguably once she opened 'delicate' investigations implicating key members of the cabinet. Nishani's nomination for her post, Adriatik Llalla, came from the High Inspectorate of Declaration and Audit of Assets and Conflict of Interests, an institution which under Llalla leadership maintained a suspicious silence on rampant cases of 
political corruption. Once in the office of the General Prosecutor, Llalla assumed the same passivity by closing up all previous and new cases of political corruption (BTI 2016b). In return for such favours, Albanian politicians made sure to vest the judiciary with strong immunity against possible investigations into their own abuses of office. Consequently, the judiciary has degraded into one of the most corrupt and least trusted institutions, arguably selling 'services' that range from the manipulation of evidence to the prolongation of cases, to the doctoring of final decisions (Republic of Albania Assembly 2015). A US- and EU-sponsored package of judiciary reforms, insistently pushed by the ruling SP majority, and which foresees the careful combing of judiciary for corruption, links to organized crime and political connections was bragged in the Albanian Parliament for two years, 2014-2016. A cross-party 'consensual' adoption of related constitutional changes, which was forcefully demanded by the foreign sponsors of reform, became the start of yet more political resistance. Specifically, key laws of the package were further delayed, blocked and boycotted by various parliamentary actors and/or denounced to the Constitutional Court. This time around even the diplomatic staff who agitated for reform, such as the EU representative in Tirana, became subject of political denigration. As of 2017, the EU singled out the start of the judiciary vetting procedure as the only remaining obstacle to open accession negotiations with Albania, but the vetting laws became also the very target of ongoing resistance and informal machination from contesting parties and judiciary structures, which have so far managed to halt any meaningful progress.

\section{Conclusions}


This article traced the role of EU's RoL promotion policy, political resistance and domestic accountability in explaining the travails of rule enforcement in the area of prosecution of political corruption. The empirical analysis drew on a cross-comparison and in-depth case studies of Croatia and Albania.

The analysis provides counterintuitive evidence on the meagre power of EU incentives to trigger domestic reform, especially when taking into account the informality of political behaviour. Our cases confirm that pro-European elites rolled to comply with the EU rules in response to associated rewards. Formal compliance, however, meant little in terms of sustainable reform. Neither specific EU rules nor tangible rewards during accession negotiations with Croatia, nor increasing clarity nor prioritization of RoL during pre-accession stages in Albania, sufficed to curtail ongoing corruption by otherwise stunch pro-European elites. Formal compliance, thus, often hides more than reveals regarding the façade nature of EU-led transfers in both countries under analysis.

Our investigation also suggests conclusive evidence on the role of domestic accountability -both horizontal and vertical - as the determining factor to explaining enforcement of EU-promoted transfers. In Croatia, an already active civil society, capitalized on EU's increased attention to RoL in order to scrutinize the implementation of relevant EU transfers during and after accession negotiations. Ultimately, it was the specialized Croatian investigative structures that succeeded to take corrupt politicians to task for the abuse of public office. Still, as the case of Albania shows, when politicized, accountability mechanisms can get entangled into and indeed serve to 
shield political corruption, often implicating the foreign funds designated for autonomous institutions into forms of political resistance.

Whether the EU can embolden accountability mechanisms is another important theoretical and empirical question pertinent to explaining rule enforcement. Our empirical analysis provides indices that would hint at the stickiness of 'initial conditions' versus the transformative power of the EU. In Croatia, civil society was active on issues of corruption before accession, and it continued to be so during and after accession. Similarly, the judiciary in Croatia, had high rankings of independence even before accession was on the table. USKOK gained additional competences during accession, but by then it was already operating within a largely independent judiciary framework. In Albania, the civil society was propelled by foreign funds, including from the EU, but it remained entangled into a vicisious circle of political services and conflict of interests. Even the US and EU's sponsoring of the entire judiciary reform didn't advance judiciary independence or investigation of political corruption. Given our findings that independent institutions can well be hostage of politics, further research is needed to investigate how the EU can propel accountability, but also how it can scrutinize local constituencies that function as political subsidiaries and implicate EU funds into forms of political resistance.

\section{Notes on Contributors}

Arolda Elbasani is a Visiting Scholar at the Center for European and Mediterranean Studies, NYU, New York. 
Senada Šelo Šabić is a research fellow at the Institute for Development and International Relations in Zagreb, Croatia.

\section{Acknowledgements}

We are grateful for feedback on different versions of this paper to Philippe Schmitter, Mietek Bodzynski, Damir Grubiša, Frank Schimmelfennig and Zoran Nechev. The anonimous reviewers gave us helpful suggestions to sharpen the analysis and emphasize our findings in a legible way.

\section{Bibliography}

Abrahams, F. (2015) Modern Albania, From Dictatorship to Democracy in Europe, New York: NYU Press.

Boduszyński, M. P. (2010) Regime Change in the Yugoslav Successor States: Divergent Paths Toward a New Europe, Baltimore: JHU Press.

Boerzel, T. and Risse, T. (2012) ‘From Europeanization to Diffusion: Introduction’, Western European Politics 35(1): 1-19.

Bosanac, G. (2012) Civil Society and EU Accession: The Croatian Experience, http://eumonitoring.ba/en/gordan-bosanac-civil-society-and-eu-accession-the-croatianexperience/ (Accessed June 2016).

BTI (2016a) Transformation Atlas, https://atlas.btiproject.org/share.php?1*2016*TS:SIX:0*CAT*2006:0 (Accessed June 2016). 
BTI (2016b) Albania Country Report, https://www.btiproject.org/fileadmin/files/BTI/Downloads/Reports/2016/pdf/BTI_2016_Albania.pdf (Accessed June 2016).

BTI (2014) Albania Country Report, http://www.bti-project.org/en/reports/countryreports/detail/itc/alb/ity/2014/itr/ecse/ (Accessed June 2016).

Carothers, T. (ed.) (2006) Promoting the Rule of Law Abroad: In Search of Knowledge, Washington D.C: Carnegie Endowment for International Peace.

Chiodi, L. (2008) 'The profession of civil society in post-communist Albania', Albanian Journal of Politics 4(1): 7-40.

Dimitrova, A. (2010). 'The new member states of the EU in the aftermath of enlargement: do new European rules remain empty shells?' Journal of European Public Policy 17(1): $137-148$.

Elbasani, A. (2009). 'EU Administrative Conditionality and Domestic Downloading', Berlin: KFG Working Paper Series, no. 2.

Elbasani, A. and Lipinski, A. (2011) 'Public Contestation and Politics of Transitional Justice: Poland and Albania Compared', EUI/SPS Working Paper Series, no. 2.

Elbasani, A. (ed.) (2013) European Integration and Transformation in the Western Balkans: Europeanization or Business as Usual? Abingdon: Routledge.

European Commission (2005) 'Croatia 2005 progress report', SEC (2005) 1424, Brussels, 9 November.

European Commission (2006) 'Enlargement strategy and main challenges 2006-2007’, COM (2006) 649, Brussels, 7 November. 
European Commission (2009) 'Croatia 2009 progress report', SEC (2009) 1333, Brussels, 14

October.

European Commission (2010) 'Commission opinion on Albania's application for membership of the European Union,' SEC (2010) 1335, Brussels, 9 November.

European Commission (2011) 'Enlargement strategy and main challenges 2011-2012', COM (2011) 666. Brussels, 12 October.

European Commission (2012) 'Enlargement strategy and main challenges 2012-2013,' COM (2012) 600, Brussels, 10 October.

Freedom House (2015) Nations in Transit 2015, https://freedomhouse.org/sites/default/files/FH_NIT2015_06.06.15_FINAL.pdf (Accessed June 2016).

Ganev, V. I. (2007) Preying on the state: The transformation of Bulgaria after 1989, New York: Cornell University Press.

Grigorescu, A. (2006) 'The corruption eruption in East-Central Europe: the increased salience of corruption and the role of intergovernmental organizations', East European Politics \& Societies, 20(3): 516-549.

Grubiša, D. (2010) 'Anti-corruption policy in Croatia: benchmark for EU accession', Politička misao, 47(5): 69-95.

Joireman, S. F. (2016) 'External conditionalities and institutional change: constructing constituencies for the rule of law in Kosovo',East European Politics and Societies 30(2): 315-331.

Kleibrink, A. (2015) Political Elites and Decentralization Reforms in the Post-Socialist Balkans, London: Palgrave Macmillan. 
Kostovicova, D. and Bojicic-Dzelilovic, V. (eds.) (2008) Transnationalism in the Balkans, Abingdon: Routledge.

Kresic, H. (2012). 'Croatia: the price of corruption,' Reuters Institute Fellowship Paper. University of Oxford.

Kuris, G. (2013). Cleaning House: Croatia Mops Up High-Level Corruption, 2005-2012, Princeton University: Innovations for Successful Societies.

Likmeta, B. (2013) 'Albania pushes on with anti-corruption package’, Balkan Insight, 5 December.

Mendelski, M. (2015) 'The EU's pathological power: the failure of external rule of law promotion in South Eastern Europe', Southeastern Europe 39(3): 318-346.

Mendelski, M. (2013) 'Where does the European Union make a Difference: Rule of law development in the Western Balkans and beyond', in A. Elbasani (ed.), European Integration and Transformation in the Western Balkans, Abingdon: Routledge, pp. 101119.

Merkel, W. (2014) 'Embedded and defective democracies ', Democratization 11 5, 33-58. Mungiu-Pippidi, A. (2010) 'Twenty years of postcommunism: the other transition', Journal of Democracy 21(1): 120-127.

Nechev, Z. (2013) 'Bolstering the rule of law in the EU enlargement process towards the Western Balkans' Clingendael Institute Policy Brief (22).

Nicolaidis, K., and Kleinfeld, R. (2012) 'Rethinking Europe's "rule of law” and enlargement agenda: the fundamental dilemma', Sigma Papers 49.

OECD (2005) 'International cooperation to fight corruption in South Eastern Europe: achievements, lessons learned and future challenges'Anti-Corruption Network for 
Transition Economies, Paris, available at

http://www.oecd.org/corruption/acn/library/37152800.pdf (Accessed June 2016).

Primatarova, A., and Deimel, J. (2012) 'Bridge over troubled waters? The role of the internationals in Albania', Centre for Liberal Strategies, Sofia.

Republic of Albania Assembly (2015) Analysis of the justice system in Albania,

Available at http://www.euralius.eu/images/pdf/Analysis-of-the-Justice-System-in-

Albania.pdf (Accessed July 2015)

Sampson, S. (1996) 'The social life of projects, importing civil society to Albania', in C. Hann

and E. Dunn (eds), Civil Society: Challenging Western Models, London: Routledge, 121142.

Schedler, A. et. al (ed.) (1999) The Self-Restraining State: Power and Accountability in New Democracies. New York, Lynne Rienner Publishers.

Schimmelfennig, F. (2007) 'European regional organizations, political conditionality, and democratic transformation in Eastern Europe', East European Politics \& Societies, 21(1): $126-141$.

Schimmelfennig, F., and Sedelmeier, U. (2006) 'Candidate countries and conditionality', in P. Graziano and M.P. Vink (eds.) Europeanization: New Research Agendas, Houndsmill: Palgrave, 88-101.

Štulhofer, A. et al. (2008) 'Combating corruption in Croatia: from expert perceptions to policyoriented action strategies and back', Crime and Culture 20: 1-23.

Vachudova, M. A. (2014) 'EU leverage and national interests in the Balkans: the puzzles of enlargement ten years on', Journal of Common Market Studies 52(1): 122-138. 
Wunsch, N. (2016) 'Coming full circle: differential empowerment in Croatia's EU accession process', Journal of European Public Policy 23 (8): 1199-1217. 